\title{
SOCIO-CRITICAL AND PROBLEM-ORIENTED APPROACH IN ENVIRONMENTAL ISSUES FOR STUDENTS' CRITICAL THINKING SKILLS DEVELOPMENT IN CHEMISTRY LEARNING
}

\author{
Agung Purwanto $(D)$, Yuli Rahmawati $($ D), Novia Rahmayanti $(D$, \\ Alin Mardiah (D), Risky Amalia (iD \\ Universitas Negeri Jakarta (Indonesia) \\ agungpurwanto@unj.ac.id,yrahmawati@unj.ac.idnoviarabmayanti27@gmail.com, \\ AlinMardiab_1311820004@mbs.unj.ac.id, amelrisky1808@gmail.com
}

Received May 2021

Accepted August 2021

\section{Abstract}

Students difficulty in relating chemistry concepts to everyday life leads to their inability to explore and developed skills needed, especially critical thinking. Therefore, this study aimed to develop students' critical thinking skills by integrating socio-critical and problem-oriented approaches to chemistry learning with environmental issues in Indonesia context need to be discussed by students. This study involved 36 grade 11 chemistry students from a high school in Jakarta, Indonesia. The qualitative methodology was employed to analyze students critical thinking development in all learning processes through multiple data collection of students interviews, reflective journals, classroom observations, worksheets, and researcher's notes. Learning was carried out in five stages: textual approach and problem analysis, clarifying the chemistry background in a lab environment, resuming the socio-scientific dimension, discussing and evaluating different points of view, and meta-reflection. While the critical thinking skills was assessed through five indicators developed by SCIT 1020: problem identification, conceptual understanding, finding relationships between concepts, developing assumptions, and drawing conclusions. The results illustrate an improvement in students' critical thinking skills, motivation, and involvement in the learning process, providing support for using a socio-critical and problem-oriented approach to chemistry learning. The socio-critical and problem-oriented can be used as an alternative approach to chemistry learning or other applicable and contextual subjects to increase student activity in the classroom and critical thinking skills in the learning process.

Keywords - Socio-critical, Problem-oriented, Critical thinking skills, Acid-base.

\section{To cite this article:}

Purwanto, A., Rahmawati, Y., Rahmayanti, N., Mardiah, A., \& Amalia, R. (2022). Socio-critical and problem-oriented approach in environmental issues for students' critical thinking skills development in chemistry learning. Journal of Technology and Science Education, 12(1), 50-67. https://doi.org/10.3926/jotse.1341

\section{Introduction}

Contemporary education seeks to increase understanding while also producing students with skills to be agents of change. Technological development is a key aspect of the development of nations and requires 
skilled human resources. Critical thinking skills are essential to support the challenges of the 21 st-century (Alkharusi, Sulaimani \& Neisler, 2019; Hashemi, 2011; Saleh, 2019).

Critical thinking is crucial to the success of science learning (Espinosa, Monterola \& Punzalan, 2013). It involves active reasoning and is used to make decisions and evaluate the complex problems of modern life (Fahim \& Pezeshki, 2012). Cognitive development is improved by science learning because it involves logical reasoning activities such as analyzing, synthesizing, reducing, and inferring (Cheng \& Wan, 2017). Students are required to recognize and solve problems using research, analysis, and evaluation to draw appropriate conclusions (Conklin, 2012). Learning outcomes improve significantly with an increase in students' critical thinking skills (Ghanizadeh, 2017; Han-Yu, Gwo-Jen \& Hong-Sheng, 2015; Mulyanto, Gunarhadi \& Indriayu, 2018).

However, a key issue in education is a lack of critical thinking skills. Some studies show that students' critical thinking skills are not fully developed due to a lack of focus on critical thinking by educators. Students are still included in the Beginning Thinker level on the critical thinking skills test. (Everett, Anderson, Wright \& Fontana, 2018; Ramos, 2018). Chemistry is a difficult subject for students who seek interesting and applicative learning. Chemistry study guides are often monotonous and lack relevant examples; therefore, students are not able to explore and develop their skills, especially critical thinking (Hakim \& Fatmaryanti, 2018; Khasanah \& Azizah, 2018). Chemistry learning must relate to the issues faced in daily life to improve students' understanding of concepts and increase critical thinking skills. Thus, contextual learning (CL) is important to be integrated into chemistry learning to produce meaningful learning for students. CL encourages students to be able to connect academic content with real situations experienced by students. It is very important to help students store information in their long-term memory that will be useful for them to apply in real life (Davtyan, 2014). It happens because the mind will naturally seek meaning in context by looking for reasonable relationships (Hull, 1995). Thus, learning occurs only when students can process new knowledge that makes sense in their context (Hull, 1995; Johnson, 2002).

The present study is in response to the author's observation of poor critical thinking skills in students and the inference that this may be due to a failure to associate the learning material with real-world applications or problems. Students are taught the concepts of science without understanding the meaning or application of that knowledge in daily life and lose motivation as a consequence.

Critical thinking skills, argumentation, and reflective thinking can be developed by socio-critical and problem-oriented learning through group discussion activities and debates on social-scientific issues (Amalia, Rahmawati \& Budi, 2019; Ridwan, Rahmawati, Nurbaity \& Hadinugrahaningsih, 2017). The socio-critical and problem-oriented approach involves the use of social issues that require reasoning and can develop students' critical thinking skills (Feierabend \& Eilks, 2011); students' use critical and creative thinking (Hadinugrahaningsih, Amalia, Fitriani \& Rahmawati, 2019; Rahmawati, Amalia \& Budi, 2020; Ridwan et al., 2017) to develop meaningful argumentation based on evidence and theoretical interpretation, thereby increasing their interest in science and technology (Feierabend \& Eilks, 2011; Marks, Stuckey, Belova \& Eilks, 2014).

The socio-critical and problem-oriented approach adds value to chemistry learning by developing students' understanding of chemical concepts and their awareness of the actions required to solve community problems. This approach enables students to understand the application of the material being studied, to realize that chemical materials are useful in daily life, and to engage in critical thinking to solve existing social issues with the knowledge gained.

This study uses acids and bases due to the common application of these materials in daily life and their relationship to environmental issues. Some studies state that students' difficulties in learning about acids and bases can be attributed to misconceptions relating to the acid-base theory, ionic equilibrium in acid-base solutions, acid-base strength, and pH calculations (Buchori, 2013; Rosalinda \& Azizah, 2017; Tarhan \& Acar-Sesen, 2012). 
Research by integrating a socio-critical and problem-oriented approach has been carried out by (Feierabend \& Eilks, 2011; Marks et al., 2014) show that relevant learning includes a social dimension to prepare students to participate in society. However, the development of critical thinking skills and the involvement of environmental issues have not been discussed in previous studies. Therefore, this study is accentuated a socio-critical and problem-oriented approach to developing students' critical thinking skills through the integration of environmental issue in acids and bases learning.

\section{Methodology}

A qualitative method was employed to analyze students' thinking skills development during the integration of socio-critical and problem-oriented approach into chemistry learning. In qualitative research, observations are made during the learning process. The research findings or data obtained are descriptive data in the form of words, spoken or pictures of the research subjects who are observed and analyzed to draw conclusions based on certain data analysis techniques (Creswell, 2009).

\subsection{Research Design}

This study was conducted during the 2018/2019 academic year at a high school in Jakarta, Indonesia. Participants were 36 grade 11 students, consisting of 14 male and 22 female students. The participants were observed informally during a chemistry class prior to the commencement of the study and some students demonstrated difficulty understanding chemistry, low motivation to learn, and unfamiliarity in applying chemistry concepts that has been learned in school to their daily lives.

The research was conducted in three stages: preliminary, implementation, and final stage as shown in the following Figure 1.

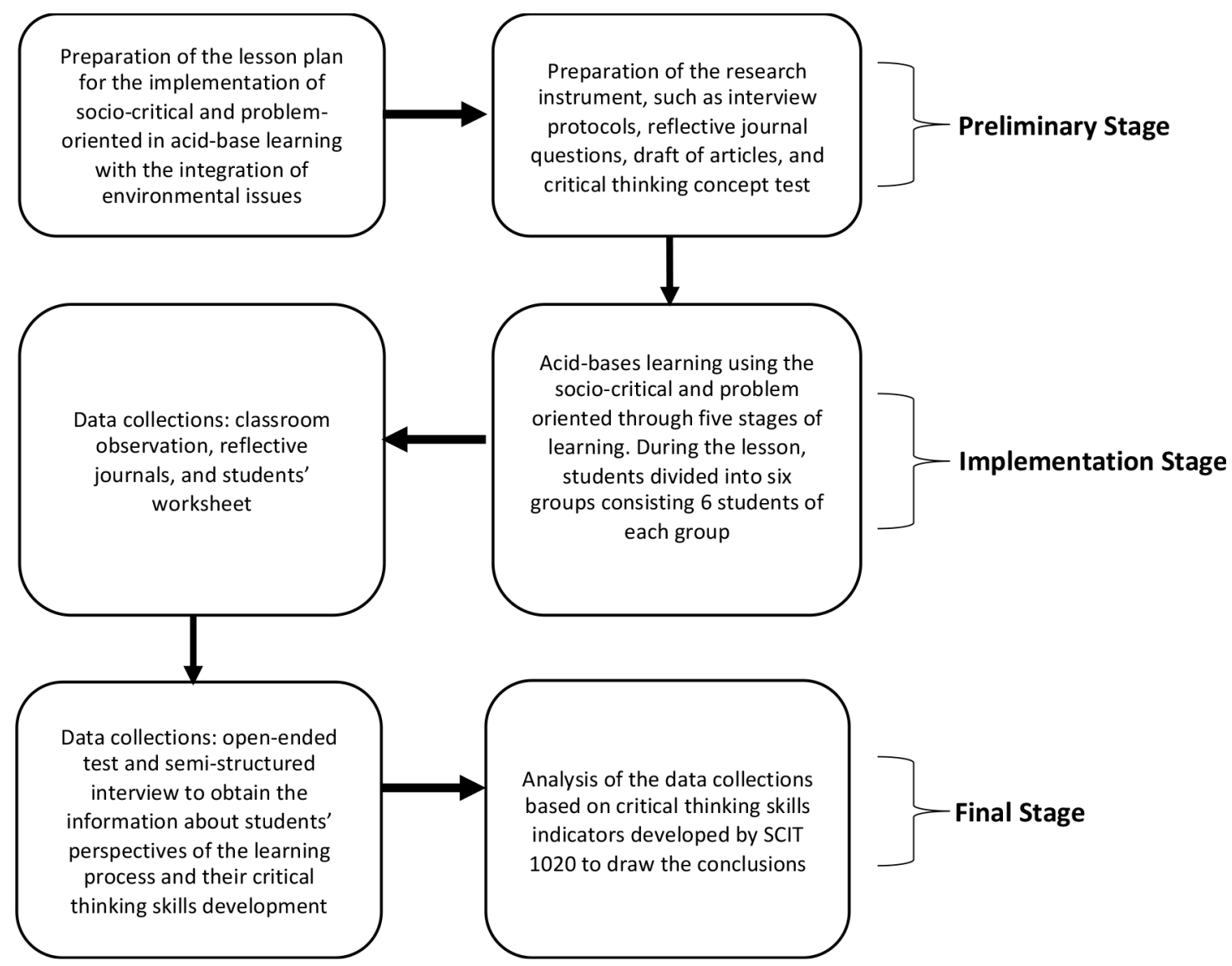

Figure 1. Research Flow and Data Collections 
The preliminary stage is carried out through various stages, namely: 1) Making observations in schools will be used as research sites to determine student learning conditions and the environment around the school; 2) Prepare a learning plan for the environmental-integrated acids and bases learning with a socio-critical and problem-oriented approach under the applicable curriculum; and 3) Designing, validating, and revising research instruments such as student worksheets, scientific articles, interview protocols, and critical thinking skills test questions on acid and base topics.

The implementation phase is carried out by applying the Socio-critical and Problem-oriented approach to environmental-integrated acids and bases learning through four stages of learning depicted in Figure 2 below.

In this study, the textual approach and problem analysis stage is done by the teacher provides media articles that introduce an acid-base concept or material and its effect on society and the environment. The participants are divided into 6 groups to discuss an article and define the problem. The issues covered in the articles and the groups allocated to each article are shown in Table 1.

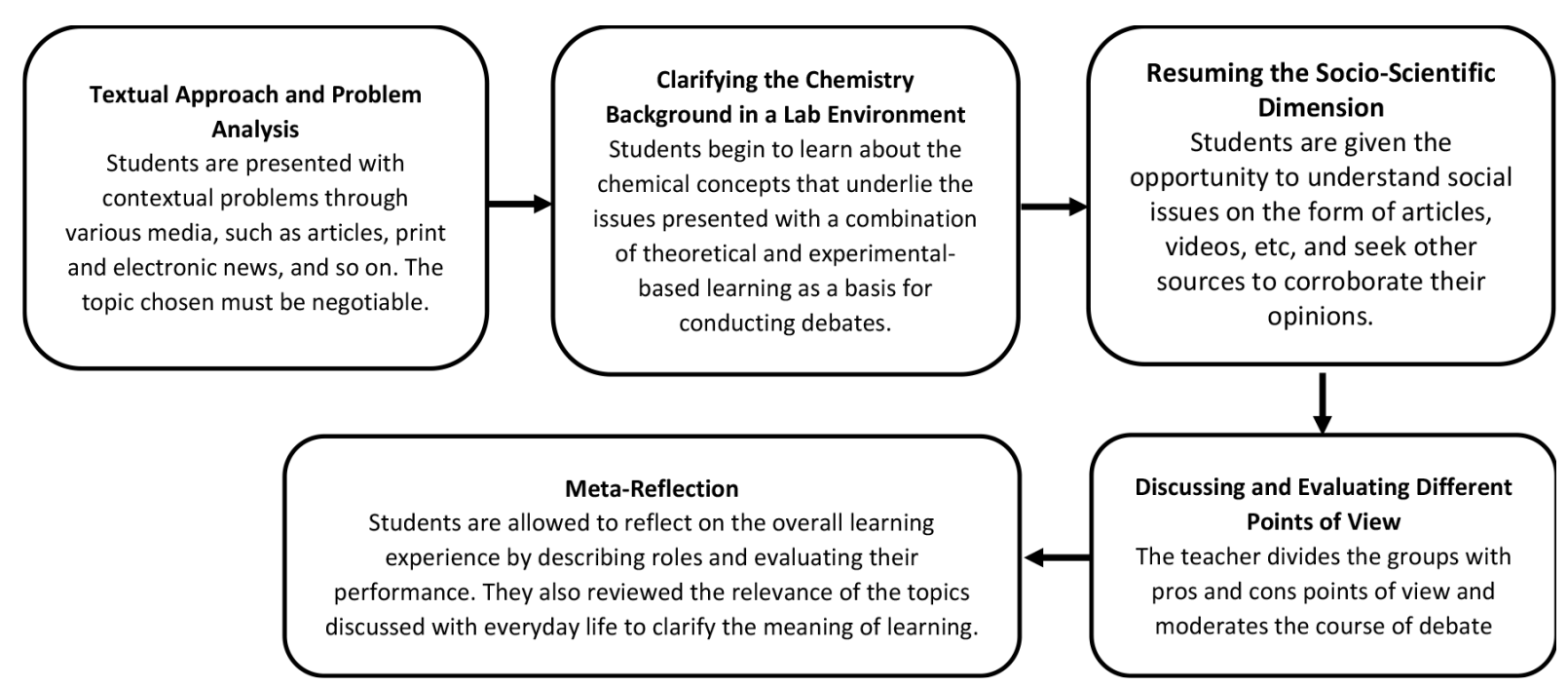

Figure 2. Socio-Critical and Problem-Oriented Learning Stages (Feierabend \& Eilks, 2011)

\begin{tabular}{|c|l|c|c|}
\hline \multirow{2}{*}{ Article } & \multicolumn{1}{|c|}{ Articles Title } & \multicolumn{2}{|c|}{ Groups } \\
\cline { 3 - 4 } & \multicolumn{1}{|c|}{ Pros } & Cons \\
\hline 1 & Because of a Speck of Waste, Damaged the Entire Waters & I & VI \\
\hline 2 & Are There Benefits of Rainwater? & V & II \\
\hline 3 & Coal Mining Consequences for Land & III & IV \\
\hline
\end{tabular}

Table 1. Environmental Articles and Groups Distribution on Different Points of View

At the clarify the chemistry background in a lab environment, for example to enhance students' understanding of the acids and bases concept of the second article, each group collects rainwater samples from various locations to test the acidity $(\mathrm{pH})$ using an acid-base titration. This practicum aims to clarify the effects of water $\mathrm{pH}$ on the environment. At the resuming the socio-scientific dimension stage, each group is given the opportunity to analyze the articles and find other sources of information to strengthen their opinions. Then at the discussing and evaluating different points of view stage, students divided into pros and cons group, while teacher plays as the debate moderator. Each group convey their thoughts to defend their opinion on the issue. Finally, the students undertake a meta-reflection, which involves thinking, analyzing, observing, and reinterpreting the activities and tasks to reflect their experiences as a form of awareness of the surrounding environment. The students also draw conclusions from these activities by linked the acids and bases conceptual understanding and real-life situation. 
In the final stage of research, students are given a critical thinking ability test through open-ended questions. In addition, the researcher conducted interviews with students to find out their views on learning chemistry using Socio-critical and Problem-oriented in the classroom. Furthermore, the researchers analyzed the data obtained through various data sources to observe students' critical thinking skills developed during the application of Socio-Critical and Problem-Oriented on environmental-integrated acids and bases learning.

\subsection{Data Collection}

Data were collected using interviews, observation sheets, reflective journals from students, teacher observation notes, worksheets (Worksheet-1, Worksheet-2, Worksheet-3) and acids-bases open-ended tests. The data obtained in this study were sourced from students, researchers, and two observers.

\subsubsection{Interviews}

Semi-structured interviews were conducted with several open-ended questions posed to students individually after the learning activities. Interviews were conducted to determine student responses to environmental integrated chemistry learning using a Socio-critical and Problem-oriented approach. The following is one of the interview questions asked.

What do you think about the learning that has been done, do you prefer learning with debate and continued with practicum or just traditional learning?

\subsubsection{Classroom Observations}

The class observation aims to observe how students respond during the implementation of learning in class. Two observers assisted the researcher when observing learning activities using a Socio-critical and Problem-oriented approach so that the assessment was not subjective. Observations were carried out in a semi-structured and direct manner concerning the observed critical thinking indicators developed by SCIT 1020.

\subsubsection{Reflective Journals}

Reflective journals are given to students at the end of each meeting. Reflective journals are diaries that students have to reflect on their thoughts or opinions about the learning process. Reflective journals aim to determine student responses, support or strengthen the results of student observations and interviews in analyzing indicators of students' critical thinking skills towards learning that has taken place. The following is an example of a common question asked in reflective journals.

How do you feel about today's lesson, are there any obstacles you face?

\subsubsection{Teacher Notes}

Teacher notes aim to observe how students respond during the implementation of learning using a Socio-critical and Problem-oriented approach in the classroom. In addition, with teacher's notes can add assessments or observations that are not visible to the observer.

\subsubsection{Worksheets}

Student worksheets are given to students to determine the development of students' critical thinking skills, prove, and see the results of practicum related to the implications of Socio-critical and Problem-oriented approaches to the environmental-integrated acids and bases learning. The student worksheet contains several questions developed based on the rubric of critical thinking skills. In this study, there are three worksheets provided following the number of scientific articles used in learning. The following are examples of questions on worksheets 1,2, and 3 . 
One of the water quality criteria in terms of chemical properties is the degree of acidity $(p H)$. In your opinion, are there any water quality criteria (in terms of chemical properties) other than $p H$ ? If yes, please describe the effect on water quality! (Worksheet 1)

The Coordinating Minister for Maritime Affairs and Investment, Lubut Binsar Pandjaitan, said that Indonesia strives to develop electric vehicles domestically. This effort is made to reduce emissions in the surrounding environment. (Reported by m.merdeka.com). In your opinion, do electric motorbikes or electric cars reduce air pollution, especially acid rain? Explain your opinion! (Worksheet 2)

According to the Head of General Mining, Distamben Kaltim, Goenoeng Djoko Hadi (2016), coal companies may produce according to their work plan (exceeding the quota). Provided that their financial and environmental performance is very good. What do you think about that statement? (Worksheet 3)

\subsubsection{Acids and Bases Open-Ended Tests}

The acid and base concept test was conducted with five open-ended questions based on critical thinking indicators developed by SCIT 1020. This open-ended question test aims to determine the implications of learning with socio-critical and problem-oriented approaches in environmental-integrated acids and bases learning on thinking skills. Student. In this study, three experts validated the test questions, consisting of 2 chemistry education lecturers at the State University of Jakarta and 1 class 11 chemistry teacher. The test was conducted after the learning activities were completed. The following is an example of a critical thinking ability test proposed.

Researchers in Germany say the carbon dioxide $\left(\mathrm{CO}_{2}\right)$ absorbed by the ocean adds to the acidity of the oceans and heats the Earth's atmosphere. It happens because when the sea absorbs $\mathrm{CO}_{2}$, the greenhouse gas will cause a reduction in the ability of the oceans to produce dimethylsulphide (DMS) gas. DMS is a gas that the ocean has made to help cool the Earth, help condense clouds and reflect sunlight to help reduce global warming. Depending on the magnitude of the increase in $\mathrm{CO}_{2}$ emissions and other factors, the Intergovernmental Panel on Climate Change (IPCC) predicts ocean acidity levels will increase by 150 percent by 2100 from the previous level in 2007. The researchers say their findings prove ocean acidification has the potential to accelerate the occurrence of global warming significantly. (Reported by greeners.co)

\subsection{Data Analysis}

In this study, all the data collected were then analyzed using the Miles and Huberman qualitative analysis technique which consisted of 3 steps: data reduction, data display, and conclusion/verification (Miles \& Huberman, 1994). Data reduction was carried out by selecting student responses according to the research focus. The data is then organized into different types depending on the Socio-critical and Problem-oriented learning syntax and the indicators of critical thinking skills developed by SCIT 1020 and presented through a matrix table or coding.

The final goal is to be achieved, aiming to justify/determine the conclusions regarding the Socio-critical and Problem-oriented approach to developing students' critical thinking skills in an environmental-integrated acids and bases learning. At this stage, the researcher looks for patterns, explanations, and relationships based on the data obtained and analyzed so that the previously incomplete picture becomes more evident along with the depth of the data analysis results. Verification is carried out in line with the research process by checking the validity of the data to ensure the credibility of the research results. To test the validity of the data, credibility criteria used are prolonged engagement, persistent observation, progressive subjectivity, and member checking (Miles \& Huberman, 1994) and trustworthiness of the data (Guba \& Lincoln, 1989). The prolonged engagement was conducted to explore student behavior and attention during the study (November 2018 to June 2019) and integrate socio-critical and problem-oriented into acids and bases learning for six weeks. Persistent observation is carried out to observe every behavior and interaction that occurs during the learning process with the help of two observers. The progressive subjectivity is carried out to monitor the study results with all data obtained during the study based on the characteristics of students' critical thinking abilities. Then, member checking aims to ensure that the data 
collected is accurate and representative according to the participants' views. All data obtained are kept private by researchers to maintain participant privacy.

\section{Results and Discussion}

This research focuses on the development of students' critical thinking skills by using a socio-critical and problem-oriented approach to explore acid-base materials present in the environment. Media articles are used as the primary information source and students are required to analyze and interpret the information.

\subsection{Socio-critical and Problem-oriented Learning}

Socio-critical and problem-oriented learning includes five stages (see Figure 1) for six meetings. Following is a description of the five stages in the context of this study.

\subsubsection{Textual Approach and Problem Analysis}

Textual approach is learning using exact and actual problems discussed controversially in society from various media sources. The issues selected can challenge students to have different views. Meanwhile, problem analysis is the process of understanding problems in the real world and proposing solutions to achieve these goals. (Feierabend \& Eilks, 2011). In this stage of the study, students analyze and critique the media source to establish its authenticity. The teacher provides the three articles and highlights the problems related to the acid-base material and its presence in the environment as shown in the following Table 2.

\begin{tabular}{|c|l|l|}
\hline No. & \multicolumn{1}{|c|}{ Article Title } & \multicolumn{1}{c|}{ Description } \\
\hline 1 & $\begin{array}{l}\text { Because of a Speck of Waste, } \\
\text { Damaged the Entire Waters }\end{array}$ & $\begin{array}{l}\text { Article about waste, if it enters the waters, will pollute the aquatic } \\
\text { environment. Waste also has the potential to have benefits for } \\
\text { humans and the environment. The teacher hopes that students can } \\
\text { present the advantages and disadvantages of waste. }\end{array}$ \\
\hline 2 & Are There Benefits of Rainwater? & $\begin{array}{l}\text { Article about pollution that will cause rainwater to become very } \\
\text { acidic in the presence of a chemical process called acid rain. Acid } \\
\text { rain causes many losses; students are expected to develop the } \\
\text { benefits and disadvantages of acid rain. }\end{array}$ \\
\hline 3 & Coal Mining Consequences for Land & $\begin{array}{l}\text { Article about coal mining pollute the soil and water because coal } \\
\text { mining results are acidic, which is often called acid mine drainage. } \\
\text { Students are expected to express opinions about the benefits and } \\
\text { disadvantages of coal mining. }\end{array}$ \\
\hline
\end{tabular}

Table 2. Description of Social Issue Articles Related to the Environmental-Integrated Acids and Bases Concept

The students then seek to understand and analyze the problem in the article. The use of social-environmental issues articles encouraged students to analyze problems quickly and relate these contextual issues to the chemistry concepts they are studying.

It turns out that there are several social problems in the surrounding environment related to this Acid-Base material, so we can begin to connect the two things. The social issues presented are also easy to understand (Reflective Journal of Student 15, 29 January 2019)

Teacher: What do you think about the articles presented in chemistry learning with a socio-critical and problemoriented approach?

Student 29: The problems within these three articles are very easy to understand and useful. We become aware of the environment too. Then how to handle it can also be easy. It doesn't need to be difficult to do.

(Interview of Student 26, 30 January 2019)

Based on the evidences above, students can analyze the problem quite well because the articles given by the teacher are pretty easy to understand and controversial in the surrounding environment. Students feel motivated by the social issues contained in the article than focused largely on delivering the content 
(Rahmawati \& Taylor, 2015). This is because they can see the relevance; the articles encourage and enable students to actively evaluate both the advantages and disadvantages of science in their lives (Gutierez, 2014; Rahmawati et al., 2020).

\subsubsection{Clarifying the Chemistry Background in a Lab Environment}

The stage of problem clarification through practicum focuses on clarifying the chemical concepts behind a social issue to stimulate students' scientific abilities. Marks et al., (2014) state that problem clarification through practicum is an action that aims to obtain an explanation of the problem related to the level of students' understanding through a practicum. At this stage, the clarification of the situation is done through practical activities. Concerns on social issues that have been submitted will be proven through practical exercises so that students can construct their thoughts on social and environmental issues that are clarified with simple, practical methods.

For example, to clarify the concept of chemistry in the second article, students were assigned to collect rainwater from their homes. There are six samples of rainwater obtained from different places in Jakarta and its surroundings to test the acidity $(\mathrm{pH})$ level with an acid-base titration practicum. The implementation of laboratory activities increases students' enthusiasm and motivation to learn.

Wow, this is like magic. The initially colorless rainwater turns pink. The color change also doesn't immediately turn pink; it disappears and then becomes light pink. Yay, I'm thrilled to succeed in this experiment. It seems I can become a chemist. (Researcher's Notes of Student 12, April 10, 2019)

Based on the results of $p H$ calculations from the experiment, does your tested rainwater include in the acid rain category? Yes, the rainwater that my group tested is acid rain because the $p H$ is less than 7, which is 5.96. The acid rain containing $\mathrm{HNO}_{3}$, it can be occur due to the reaction between the evaporate water and nitrogen gas (which has composition about $>70 \%$ ) in the air. (Worksheet 2 of Student 35, 23 April 2019)

Based on the description above, students seemed very enthusiastic about doing an acid-base titration practicum to understand better the chemistry concepts that are the background in the article presented. It is in line with the study of Astuti, Andayani, Al-Idrus and Purwoko (2019), that students seem enthusiastic about the practical method based on everyday life because it has a positive influence on students' science process skills, compared to conventional practicum methods. Futhermore, the practical exercise actively engages the students in chemistry learning, thus developing their conceptions (Prima, Utari, Chandra, Hasanah \& Rusdiana, 2018), conceptual and theoretical knowledge, scientific inquiry skills, problem-solving abilities and awareness of the interactions between science, technology, society, and the environment (Hodson, 1996).

\subsubsection{Identifying the Socio-scientific Dimension}

This stage focuses on summarizing the facts in the information to strengthen the argument to develop reading interest and be critical in finding other references. Marks et al. (2014) state that summarizing the socio-scientific dimension is a way of reflection that expands scientific information to support individual or community decisions. Students search for scientific information from various sources and critically evaluate the references before they are used, to broaden and strengthen the facts presented in the debating activity.

Before the debate begins, students look for other sources relevant to the issue/problem that will be debated in their respective groups. Cooperation between groups is quite good. (Classroom Observation, 29 January 2019)

I look for other sources on the internet then when we have the topic of our conversation, we immediately discuss and note so as not to forget when we want to express an opinion. Then if sometbing is still lacking, we look for it again. (Interview of Student 30, 30 January 2019)

Based on the research evidences above, students have prepared debates well enough to add insight about social issues to strengthen their opinions. Students improve their critical thinking skills by analyzing and synthesizing information on scientific social issues. The research required to support arguments that have 
moral and ethical consequences encourages consideration of actions in local contexts (Burek \& Zeidler, 2015). This finding is also in accordance with Eilks, Marks and Feierabend (2008) which states that the Socio-critical and Problem-oriented approach can add insight to science and enhance collaboration between groups, increase the interest in science and technology, and students can demonstrate the relevance of science in social discussion and decision making.

\subsubsection{Discussing and Evaluating Different Points of View}

This stage involves the debate of social issues from different perspectives, and enables students to engage in a discussion according to the available evidence. Discussion and evaluation from different points of view is a way to unite the decisions of each individual by explaining, evaluating, and comparing different perspectives on the problem (Stolz, Witteck, Marks \& Eilk, 2014). In this study, students are divided into two groups of different points of view to debate about the theme that has been specified (see Figure 3 ).
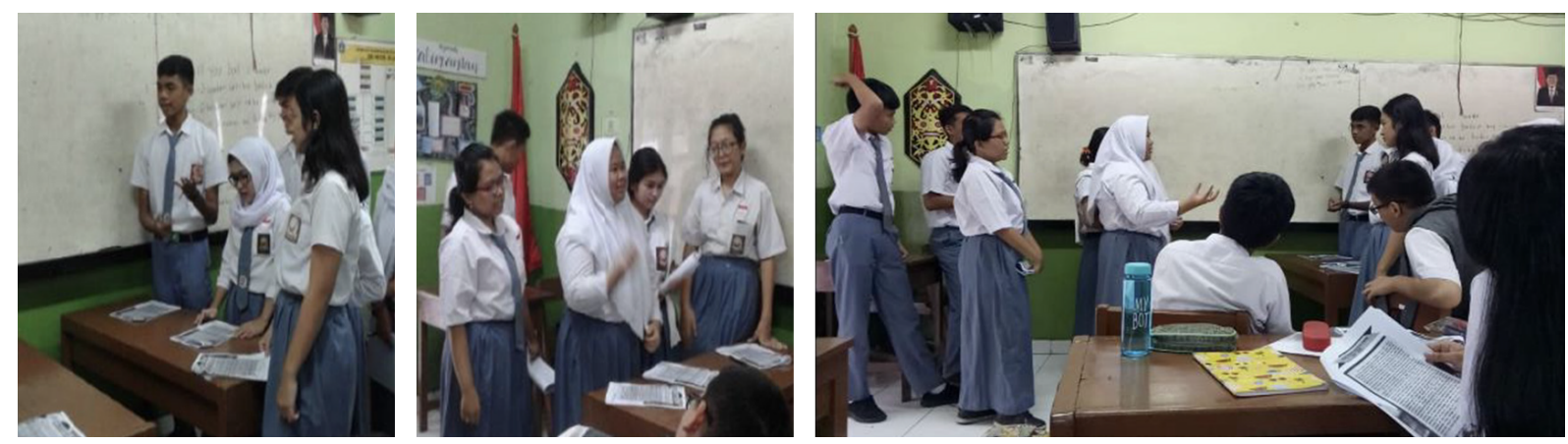

Figure 3. The Debate on the Second Article "Are There Benefits of Rainwater?"

Cons: In our opinion, acid rain does more harm than good.

Pros: Rainwater has many benefits for the environment, such as agricultural irrigation, preventing soil erosion, and generating electricity. In addition, rainwater plays a vital role in buman life, namely for drinking water supplies, bathing, washing, and others.

Cons: But did you know that there is a rain phenomenon that contains acid compounds? Yes, acid rain has a high acid concentration, so the $p H$ is below 5.6 and is corrosive. Therefore, acid rain causes a lot of losses.

Pros: In our opinion, the rainwater that falls into the river has changed to $p H$, so it is safe.

Cons: Not all rivers have a buffer system when exposed to a bit of acid; the $p H$ will remain stable. So, acid rain that falls into waterways can cause the $p H$ of river water to decrease.

Pros: But acid rain also benefits the ecosystem, as it contains many minerals that are beneficial for plants and fish in rivers.

Cons: But the disadvantages of acid rain still outweigh the benefits. For example, what if the villagers do not know that the river water is contaminated and still use it to meet their daily needs?

Pros: Villagers use healthy water safe from rain, so the water is still pure from groundwater sources.

Cons: Even so, the point is that acid rain is worse for the environment and health.

Pros: Yes, but we can handle acid rain because it happens because of human activities, so we also bave to deal with it, such as doing $3 \mathrm{R}$ (Reuse, Reduce, and Recycle).

Based on the snippet above, it can seem that the debate between groups cons and pros is quite capable of conveying their opinions with the existing facts. Argumentation-based science learning activities will 
encourage students to provide data, evidence, and appropriate theories (Robertshaw \& Campbell, 2013) and linked their scientific understanding to support arguments against a real-life problem (Pimvichai, Buaraphan \& Yuenyong, 2019). Besides, the debate enhances students' enthusiasm as seen at the following interview.

The debate was very exciting, but what became my difficulty was when there was an opportunity to reply to statements from our debate opponents. They have mastered the material, then we reply to their statement, but they are very able to reply to our group's statement. Now we can't do anything, shame too. (Interview of Student 34, 30 January 2019)

The students enthusiastically express their opinions, which is uncommon in their chemistry class. Each group makes a strong argument that is supported by evidence. Through the process of debate, the interaction between students increases significantly and they provide positive, complex, and in-depth responses to issues using a wider variety of explanations (Gutierez, 2014).

\subsubsection{Meta-reflection}

In this stage, the students reflect on the way in which different information and points of view are presented, discussed, and used in the community (Skerrit, Fletcher \& Kearney, 2015). This stage measures the process of thinking, analyzing, observing, and interpreting the information presented. At the end of each lesson, the students reflect on their knowledge of the issues studied, finalize their conclusions, and present solutions to the problems.

If I become a citizen of the area near waste or pollution, I will clean up the trash, not litter, not using a vebicle when going to a nearby place. (Student interview, Student 11, January 30, 2019)

For example, if I become a researcher, I want to make works or products that are environmentally friendly. I actually want to make a tool for processing super-fast waste, so the environment is free from garbage, waste, and pollution. (Student interview, Student 5, January 30, 2019)

These interview transcript extracts demonstrate that students are able to draw conclusions, provide solutions, convey their reflections, and understand their role in caring for the environment. Critical reflection is an essential aspect of learning development in students (Helali, 2015).

This study demonstrates that students are actively and enthusiastically engaged in learning when using the socio-critical and problem-oriented approach. In addition, curiosity, self-confidence, and the ability argue increase during the learning process. The socio-critical and problem-oriented approach can trigger motivation to learn and encourages the process of evaluation and self-reflection in the classroom; students can understand and display the relevance of science in social discussion and decision making (Marks \& Eilks, 2010).

\subsection{Analysis of Critical Thinking Skills}

The ability to think critically can improve attention and observation and can allow the student to choose important information, improve their ability to respond to information, and improve analytical skills (Yunarti, 2011). Based on SCIT 1020 (2013), there are five indicators of critical thinking skills: problem identification, conceptual understanding, establishing relationships between concepts, defining assumptions, and providing conclusions. The acids and bases open-ended test results are categorized into five criteria of critical thinking skills level: Very Good, Good, Fair, Bad, and Very Bad, with 4, 3, 2, 1, 0 points, respectively. The following is the general result data from the average assessment of all indicators of critical thinking skills. 


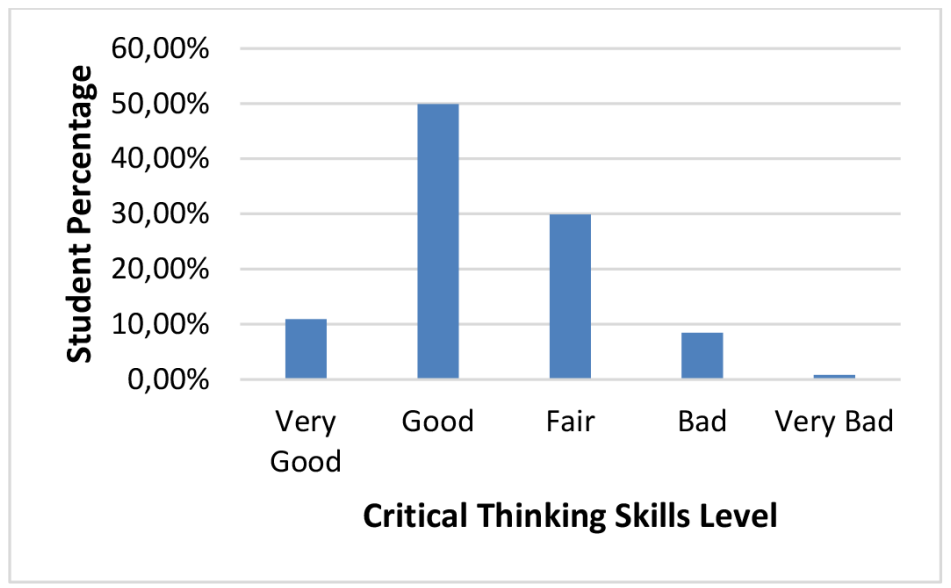

Figure 4. Histogram of Students' Critical Thinking Skills Level Achievement

Based on Figure 4, the highest percentage of students among other criteria is a good criterion. It shows that students' critical thinking skills in all indicators have developed well; in other words, the balance in all hands is included in good criteria. The discussion of each indicator is as follows.

\subsubsection{Problem Identification}

Problem identification is the first step in problem solving and decision making (Adams \& Hamm, 2010). In this study, students are assessed on their ability to answer a question relating to the effect of an acids and bases on the environment.

Question: Identify the social issues in the article entitled "Because of a speck of waste, damaged the entire waters" from different points of view!

Answer: I will have a pro view if waste can damage waters because waste dumped into rivers can damage underwater ecosystems. For example, solid waste thrown into the river will block sunlight into the river/lake so that the photosynthesis process of aquatic plants is hampered. Moreover, industrial waste in the form of liquid is challenging to filter if dumped into the river. However, from a contra perspective, I see that the waste will not damage the waters if appropriately treated. For example, inorganic waste can be recycled into materials with a selling value, such as making toys, accessories, etc. (Worksheet 1 of Student 34, 29 January 2019)

Student 34's answer above shows that he/she has been able to identify the pros and cons of the question in article 1. The integration of contextual problems provide opportunities for students to develop their critical thinking skills through problem identification and analysis so that learning becomes more effective (Suryawati \& Osman, 2017). In addition, through debate activities, students also learn to practice their thinking skills through issue analysis to decision-making to solve problems.

Pros: We believe that waste has benefits. Waste is divided into two types, namely organic and inorganic. Organic waste can be used as fertilizer and fuel. Meanwbile, inorganic waste can be recycled as basic materials for handicrafts.

Cons: However, behind some of these benefits, waste has many negative impacts on the environment. Especially if liquid waste from industrial processes enters the waters, it can threaten the survival of flora and fauna.

Both groups are able to identify and express the core problems and support their allocated side in the debate. The students state reasons that are clear and easy to understand. During the debate, most students are able to identify the core problems in an issue, demonstrating a development in their critical thinking skills. Students who think critically are those who can identify problems, evaluate and construct arguments, and propose appropriate solutions (Elder \& Paul, 2020). 


\subsubsection{Conceptual Understanding}

Conceptual understanding does not memorize but for a deeper understanding (Holme, Luxford \& Brandriet, 2015). Conceptual understanding is demonstrated in the second debate, in which Groups 2 and 5 discuss the article on the benefits of rainwater. While most students demonstrate an understanding of the acid-base concept, the pro-article group experience difficulty in expressing their argument in relation to the article, only conveying the benefits of rainwater in general. This is captured by the observers:

Groups 2 and 5 are good enough to link concepts during the debate. However, in group 5 (pro) they have not been able to relate it to the concept of acid-base. (Classroom Observation, 29 January 2019)

During the session 2 debate, the pro group had not yet been seen linking the acid-base concept. (Classroom Observation, 29 January 2019)

These statements are verified by the debate transcript below, in which the pro-article group does not link the article to the acid-base concept:

Pros: There are general benefits of rainwater such as agriculture, irrigation, reducing soil erosion, water-powered electricity generation, improving air quality, healthy drinking water supplies, making lakes or reservoirs not dry, so that they can be used as a place for aquaculture and public needs for bumans, like washing, bathing and so on.

Cons: Acid rain is rain that has a bigh acidic $p H$ concentration below 5.6. Naturally acidic is $p H$ below 6. Acid rain is not good for human bealth; moreover, acid rain may contain carbonates and bicarbonates that are not good.

The cons-group shows a clear understanding of the acid-base concept by defining the $\mathrm{pH}$ of natural rainwater and the $\mathrm{pH}$ of acid rain. Most students are able to understand the concept in an issue, and show developing critical thinking skills in conceptual understanding. The learning process hones students' ability to understand and apply concepts using critical thinking skills (Saputro \& Gunansyah, 2011). Understanding concepts is mastering something with a mind that contains categories of stimulation that have general characteristics, so understanding concepts is a very important aspect of learning (Hamalik, 2009).

\subsubsection{Establishing Relationships between Concepts}

The relationship between concepts is a state of the interrelationship between one idea and another (Paul, Arkin, Aksaray, Roy \& Howard, 2018). The integration of socio-critical and problem-oriented approach engage students to connect the concepts of chemistry with environmental, social, and biological concepts as seen in the following student's answer for the acids and bases open-ended test.

Question: Indonesia is the second-largest waste producer in the world. It requires the right solution to minimize it so that the environment does not get worse. In your opinion, what is the most appropriate solution to reduce waste?

Answer: The right solution to reduce or minimize waste so that the environment does not get worse is by: a) Neutralization is the reaction between an acid and a base to produce salt and water. Neutralization can be done in two systems, namely batch or continuous, depending on the wastewater flow. Batch system neutralization is usually used when the flow is low and the quality of wastewater is relatively bigh. A continuous neutralization system is used if the flow rate is significant, so it needs to be equipped with an automatic control device. Neutralization of acidic waste can add $\mathrm{Ca}(\mathrm{OH})_{2}$ or $\mathrm{NaOH}$. Meamwbile, alkaline waste can add $\mathrm{H}_{2} \mathrm{SO}_{4}, \mathrm{HC}, \mathrm{HNO}_{3}$, and $\mathrm{H}_{3} \mathrm{PO}_{4}$; and b) Precipitation is the reduction of dissolved materials by adding solid chemicals. Precipitation is used to remove heavy metals, sulfates, fluorides, and phosphates. The compound used is usually lime, combined with calcium chloride, magnesium chloride, aluminum chloride, and iron salts. (Test Answer of Student 36, 6 February 2019)

Based on the research finding above, it can conclude that students' critical thinking skills on the indicators of the relationship between concepts have developed well. It is in accordance with Alatas (2015), which states that in thinking skills, students can train and develop their cognitive intelligence and connect various facts or information with the knowledge they already have to predict the final result formulated. 


\subsubsection{Defining Assumptions}

An assumption is a belief, idea, conjecture, or thought possessed by an individual, group of people, or experts regarding an object (Cohen, Baumgartner \& Hunter, 2008). The development of students' abilities in making assumptions is identified through the following student interview excerpt.

Teacher: A farmer adds fertilizer to his crops. The farmer often uses a variety of fertilizers. However, over time the plants wither, and the soil becomes dry. What do you think is wrong with the farmer's treatment?

Answer: In my opinion, the treatment of farmers who use various fertilizers and their irregular use is wrong, so the soil becomes dry, and the plants wither. I've read that fertilizer contains nitrogen and other elements. In the ground, there is also an element of nitrogen; if you give too much fertilizer, then the soil will harden and cause the plant to wither... (Interview of Student 34, 30 January 2019)

The findings above show that students have been able to express their thoughts on a problem. Following Halpern's study cited in Noone and Hogan (2018), states that critical thinking as a part of higher-order thinking skills comprised verbal reasoning, argument analysis, estimating the possibilities, problem-solving, and decision making. Learning chemistry by integrating contextual problems can encourage students to develop their thinking to solve problems in everyday life by combining the chemistry concepts they have learned. Thus, learning chemistry becomes useful and meaningful (Hadinugrahaningsih, Rahmawati \& Ridwan, 2017).

\subsubsection{Providing Conclusions}

The conclusion is a proportion (sentence delivered) taken from several premises (ideas of thought) with the rules of inference (applicable). Formulating several possible solutions and drawing conclusions are important aspects of critical thinking. (Ratcliffe \& Grace, 2003). Observations from the first debate demonstrate the students' skills in drawing conclusions; however, the groups do not provide solutions.

In the session one debate, they were able to draw conclusions and develop a good solution. (Classroom Observation, 29 January 2019)

In groups 1 and 6, they were able to draw conclusions and make solutions to problems well. (Classroom Observation, 29 January 2019)

These statements can be verified by the following debate transcript:

Pros: The most common type of waste in Indonesia is plastic waste, not liquid waste. Therefore, Indonesia must reduce the amount of plastic waste by limiting its use.

Cons: Not only plastic waste, there is also a lot of liquid waste and must be handled. In essence, both physical and non-physical waste must be cleaned so as not to pollute the environment.

Pros: The conclusion from our group is that waste that is possible can be recycled, don't throw it away, but can be created into items that are worth selling. Meanwhile, waste that cannot be reused needs to be managed first before being discharged into the environment.

Based on the snippet of the debate, it can see that students has been able to draw conclusions and make solutions logically and adequately. However, the two groups still have not expanded the discussion of their findings and solutions so that the audience can also apply them to the surrounding environment. Each student has the ability to consider relevant information and form conjectures in order to draw conclusions as problem solving (Facione, 2011).

Based on the overall analysis, the following is the level of achievement of each indicator of students' critical thinking skills. 


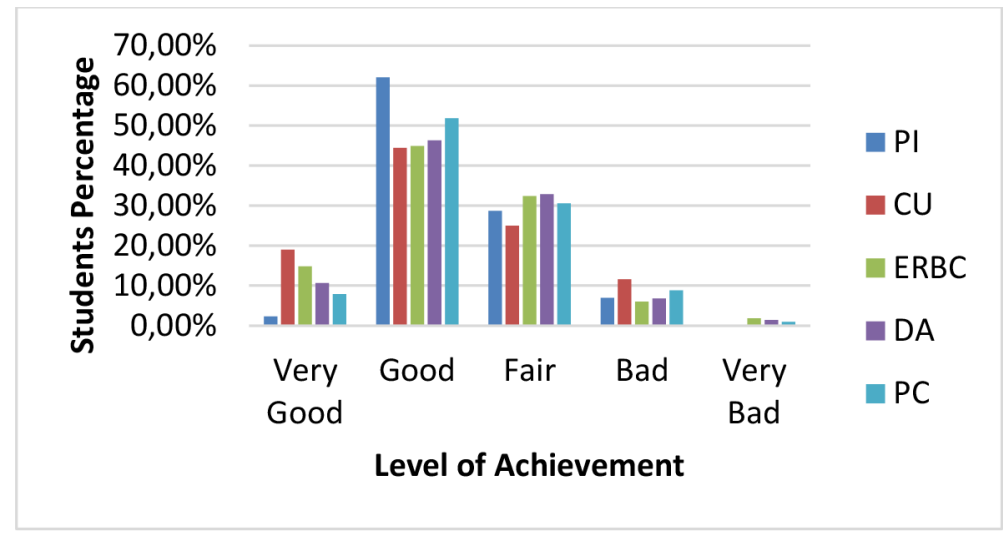

Note: PI: Problem Identification; CU: Conceptual Understanding; ERBC: Establish

Relationship between Concept; DA: Defining Assumptions; PC: Providing Conclusions

Figure 5. Histogram of Each Indicator of Critical Thinking Skills Level Achievement

Based on the Figure 5, the highest critical thinking skills of students is an indicator of problem identification on good criteria. Student can identify important questions from the topic with a lot of confusion. Critical thinking requires higher mental and intellectual abilities to identify and explore problems and find solutions (Amir, 2015). The results also show that the conceptual understanding indicator has the highest critical thinking skills on excellent criteria. This shows that the issues presented can stimulate students' conceptual understanding even though there are only a few students who understand the concept.

\section{Conclusions}

Applying the socio-critical and problem-oriented approach to environmental issues can improve students' critical thinking skills in acids and bases learning. For the overall results, a big number of students have reached the good level of critical thinking skills with problem identification indicator is considered to have experienced significant development as a basic ability in solving a problem. The integration of contextual issues encourages students' curiosity, enthusiasm, motivation, and argumentation skills demonstrated during learning process and their involvement in responding to social issues presented through discussions and debates and during the practical laboratory activity. Therefore, this study supports the socio-critical and problem-oriented approach as an alternative approach to chemistry learning or other subjects that is applicable and contextual in daily life and the environment.

This study highlights some challenges in developing students' critical thinking skills through the socio-critical and problem-oriented approach. The teacher must closely monitor the debate sessions to ensure the class conditions are conducive to a discussion that will not be disrupted. Some students are shy or afraid to ask questions; therefore, the teacher must provide stimulus or encouragement to students to engage in the activity. Teacher tried to put more emphasis on students' understanding and students' empowerment which strengthened the students' engagement during the lessons (Rahmawati, Koul \& Fisher, 2015). Furthermore, this type of learning can be time-consuming, and time management must be in accordance with the overall learning plan to ensure other subjects are not negatively affected.

\section{Declaration of Conflicting Interests}

The authors declared no potential conflicts of interest with respect to the research, authorship, and/or publication of this article.

\section{Funding}

The authors received no financial support for the research, authorship, and/or publication of this article. 


\section{References}

Adams, D., \& Hamm, M. (2010). Demystify Math, Science, and Technology: Creativity, Innovation, and ProblemSolving. Rowman \& Littlefield Education.

Alatas, F. (2015). Hubungan Pemahaman Konsep Dengan Keterampilan Berpikir Kritis Melalui Model Pembelajaran Treffinger Pada Mata Kuliah Fisika Dasar. Edusains, 6(1), 87-96.

https://doi.org/10.15408/es.v6i1.1103

Alkharusi, H.A., Sulaimani, H.A., \& Neisler, O. (2019). Predicting Critical Thinking Ability of Sultan Qaboos University Students. International Journal of Instruction, 12(2), 491-504.

https://doi.org/10.29333/iji.2019.12231a

Amalia, R., Rahmawati, Y., \& Budi, S. (2019). Pengembangan Keterampilan Argumentasi Calon Guru Kimia Melalui Pendekatan Socio Critical and Problem Oriented. Jurnal Tadris Kimiya, 1(Juni), 91-104. https://doi.org/10.15575/jtk.v4i1.4816

Amir, M.F. (2015). Proses Berpiki Kritis Ssisw Sekolah Dasar Dalam Memecahkan Masalah Berbentuk Soal Cerita Matematika Berdasarkan Gaya Belajar. Jurnal Math Educator Nusantara Vlolume, 01(02), 159-170.

Astuti, S.W., Andayani, Y., Al-Idrus, S.W., \& Purwoko, A.A. (2019). Penerapan Metode Praktikum Berbasis Kehidupan Sehari-hari Terhadap Keterampilan Proses Sains Siswa Kelas XI MIA MAN 1 Mataram. Chemistry Education Practice, 1(2), 20. https://doi.org/10.29303/cep.v1i2.952

Buchori, M. (2013). Identifikasi Tingkat, Jenis, dan Faktor-Faktor Penyebab Kesulitan Siswa MA Negeri Wlingi dalam Memahami Materi Indikator dan pH Larutan Asam-Basa. Universitas Negeri Malang, 1-11.

Burek, K., \& Zeidler, D.L. (2015). EcoJustice, Citizen Science and Youth Activism. Seeing the Forest for the Tress! Conservation and Activism Through Socioscientific Issues, February 2017, 179-191.

https://doi.org/10.1007/978-3-319-11608-2

Cheng, M.H.M., \& Wan, Z.H. (2017). Exploring the effects of classroom learning environment on critical thinking skills and disposition: A study of Hong Kong 12th graders in Liberal Studies. Thinking Skills and Creativity, 24, 152-163. https://doi.org/10.1016/j.tsc.2017.03.001

Cohen, K.B., Baumgartner, W.A., \& Hunter, L. (2008). Software testing and the naturally occurring data assumption in natural language processing. SETQA-NLP'08: Software Engineering, Testing, and Quality Assurance for Natural Language Processing, 23-30. https://doi.org/10.3115/1622110.1622116

Conklin, W. (2012). Higher-Order Thinking Skills to Develop 21st Century Learners. Shell Educational Publishing, Inc.

Creswell, J.W. (2009). Reasearch Design; Quantitative, Qualitative and Mixed Methods Approach. SAGE Publications.

Davtyan, R. (2014). Contextual Learning. ASEE Zone I Conference.

Eilks, I., Marks, R., \& Feierabend, T. (2008). Science education research to prepare future citizens: Chemistry learning in a sociocritical and problem-oriented approach. In Bernd, R., \& Eilks, E. (Eds.), Promoting successful science education (75-86). Shaker.

Elder, L., \& Paul, R. (2020). Critical thinking: Tools for taking charge of your learning and your life. Foundation for Critical Thinking.

Espinosa, A.A., Monterola, S.L.C., \& Punzalan, A.E. (2013). Career-oriented performance tasks: Effects on students' interest in Chemistry. Asia-Pacific Forum on Science Learning and Teaching, 14(2).

https://doi.org/10.1155/2013/834584 
Everett, A.C., Anderson, O.S., Wright, M.C., \& Fontana, M. (2018). Longitudinal Assessment of Critical Thinking Skills Across a Dental Curriculum. Journal of Dental Education, 82(9), 921-928.

https://doi.org/10.21815/JDE.018.088

Facione, P.A. (2011). Critical Thinking: What It Is and Why It Counts. In Insight assessment. Available at: https://www.insightassessment.com/CT-Resources/Teaching-For-and-About-Critical-Thinking/Critical-Thinking-What-ItIs-and-Why-It-Counts/Critical-Thinking-What-It-Is-and-Why-It-Counts-PDF

Fahim, M., \& Pezeshki, M. (2012). Manipulating Critical Thinking Skills in Test Taking. International Journal of Education, 4(1), 153-160. https://doi.org/10.5296/ije.v4i1.1169

Feierabend, T., \& Eilks, I. (2011). Teaching the Societal Dimension of Chemistry Using a Socio-Critical and Problem-Oriented Lesson Plan Based on Bioethanol Usage. Journal of Chemical Education, 88(9), 1250-1256. https://doi.org/10.1021/ed1009706

Ghanizadeh, A. (2017). The interplay between reflective thinking, critical thinking, self-monitoring, and academic achievement in higher education. Higher Education, 74(1), 101-114.

https://doi.org/10.1007/s10734-016-0031-y

Guba, E.G., \& Lincoln, Y. (1989). Fourth generation evaluation. Sage Publications.

Gutierez, S.B. (2014). Integrating Socio-Scientific Issues to Enhance the Bioethical Decision-Making Skills of High School Students. International Education Studies, 8(1), 142-151. https://doi.org/10.5539/ies.v8n1p142

Hadinugrahaningsih, T., Amalia, R., Fitriani, E., \& Rahmawati, Y. (2019). Chemistry students' soft skills development through the integration of Think Pair Square (TPSq) using a socio critical and problem oriented approach in acid-based learning Chemistry students' soft skills development through the integration of Think Pa. Journal of Physics: Conference Series, 14(5).

https://doi.org/10.1088/1742-6596/1402/5/055075

Hadinugrahaningsih, T., Rahmawati, Y., \& Ridwan, A. (2017). Developing 21st century skills in chemistry classrooms: Opportunities and challenges of STEAM integration. AIP Conference Proceedings, 1868(August). https://doi.org/10.1063/1.4995107

Hakim, L., \& Fatmaryanti, D. (2018). Studi Pendahuluan Pengembangan Media Pembelajaran Berbasis Booklet Etnosains Fotografi Untuk Meningkatkan Kemampuan Berpikir Kritis Siswa. Proceeding of The 7th University Research Colloqium 2018 (223-227).

Hamalik, O. (2009). Kurikulum dan Pembelajaran. Bumi Aksara.

Han-Yu, S., Gwo-Jen, H., \& Hong-Sheng, C. (2015). An Integrated Contextual and Web-Based Issue Quest Approach to Improving Students' Learning Achievements, Attitudes and Critical Thinking. Journal of Educational Technology and Society, 4(18), 299-311.

Hashemi, S.A. (2011). The Use of Critical Thinking in Social Science Textbooks of High School: A Field Study of Fars Province in Iran. Online Submission, 4(1), 63-78.

Helali, F. (2015). Building Taxonomy Knowledge 'Systemic Ergonomics Intervention Work' - a Product Joining up practice with theory in an Industrially Developing Country and its 'Meta-Reflection' This paper describes a model of systemic intervention based on building tax.

Hodson, D. (1996). Practical work in school science: exploring some directions for change. International Journal of Science Education, 18(7), 755-760. https://doi.org/10.1080/0950069960180702

Holme, T.A., Luxford, C.J., \& Brandriet, A. (2015). Defining Conceptual Understanding in General Chemistry. Journal of Chemical Education, 92(9), 1477-1483. https://doi.org/10.1021/acs.jchemed.5b00218 
Hull, D. (1995). Who Are You Calling Stupid?: The Revolution That's Changing Education. CORD Communication.

Johnson, E.B. (2002). Contextual Teaching and Learning: What It is and Why It's Here to Stay. Corwin Press.

Khasanah, N., \& Azizah, U. (2018). Train Students' Critical Thinking Skill Through the Implementation of Cooperative Learning Model Type Group Investigation (GI) on Matter of Reaction Rate in SMA Negeri 1 Manyar. Unesa Journal of Chemical Education, 7(1), 81-86.

Marks, R., \& Eilks, I. (2010). Research-based development of a lesson plan on shower gels and musk fragrances following a socio-critical and problem-oriented approach to chemistry teaching. Chemistry Education Research and Practice, 11(2), 129-141. https://doi.org/10.1039/C005357K

Marks, R., Stuckey, M., Belova, N., \& Eilks, I. (2014). The Societal Dimension in German Science Education - From Tradition towards Selected Cases and Recent Developments. EURASLA Journal of Mathematics, Science and Technology Education, 10(4), 285-296. https://doi.org/10.12973/eurasia.2014.1083a

Miles, M., \& Huberman, A. (1994). Qualitative Analysis: An Expanded Source Book (2nd ed.). SAGE.

Mulyanto, H., Gunarhadi, G., \& Indriayu, M. (2018). The Effect of Problem Based Learning Model on Student Mathematics Learning Outcomes Viewed from Critical Thinking Skills. International Journal of Educational Research Review, 3(2), 37-45. https://doi.org/10.24331/ijere.408454

Noone, C., \& Hogan, M.J. (2018). A randomised active-controlled trial to examine the effects of an online mindfulness intervention on executive control, critical thinking and key thinking dispositions in a university student sample. BMC Psychology, 6(1), 1-18. https://doi.org/10.1186/s40359-018-0226-3

Paul, R., Arkin, J., Aksaray, D., Roy, N., \& Howard, T.M. (2018). Efficient grounding of abstract spatial concepts for natural language interaction with robot platforms. The International Journal of Robotics Research, 37(10), 1269-1299. https://doi.org/10.1177/0278364918777627

Pimvichai, J., Buaraphan, K., \& Yuenyong, C. (2019). Development of Grade 10 Students' Scientific Argumentation through the Science-Technology-Society Learning Unit on Work and Energy. Journal of Technology and Science Education, 9(3), 428. https:/ /doi.org/10.3926/jotse.527

Prima, E.C., Utari, S., Chandra, D.T., Hasanah, L., \& Rusdiana, D. (2018). Heat and temperature experiment designs to support students' conception on nature of science. Journal of Technology and Science Education, 8(4), 453. https://doi.org/10.3926/jotse.419

Rahmawati, Y., Amalia, R., \& Budi, S. (2020). Challenging Students' Critical Thinking Skills: Integrating Socio-critical and Problem-oriented Approach in Nanoscience and Nanotechnology Learning. Universal Journal of Educational Research, 8(1), 98-104. https://doi.org/10.13189/ujer.2020.080111

Rahmawati, Y., Koul, R., \& Fisher, D. (2015). Teacher-student dialogue: transforming teacher interpersonal behaviour and pedagogical praxis through co-teaching and co-generative dialogue. Learning Environments Research, 18(3), 393-408. https://doi.org/10.1007/s10984-015-9191-4

Rahmawati, Y., \& Taylor, P.C. (2015). Moments of critical realisation and appreciation: a transformative chemistry teacher reflects. Reflective Practice, 16(1), 31-42. https://doi.org/10.1080/14623943.2014.944142

Ramos, J.R. (2018). Critical Thinking Skills Among Senior High School Students and Its Effect in Their Academic Performance. International Journal of Social Sciences and Humanities, 2(3), 61-73.

Ratcliffe, M., \& Grace, M. (2003). Science Education for Citizenship: Teaching Socio-scientific Issues. McGraw-Hill Education. 
Ridwan, A., Rahmawati, Y., Nurbaity, \& Hadinugrahaningsih, T. (2017). Integration of a Socio-Critical and Problem Oriented Approach In Chemistry Learning for students' Soft Skills Development. MIER Journal of Educational Studies, Trends \& Practices, 7(1), 33-41.

Robertshaw, B., \& Campbell, T. (2013). Constructing arguments: Investigating pre-service science teachers' argumentation skills in a socio-scientific context. Science Education International, 24(2), 195-211. http://search.ebscohost.com/login.aspx?direct=true\&db=eue\&AN=91508841

Rosalinda, E., \& Azizah, U. (2017). Penerapan Model Pembelajaran Kooperatif Tipe Numered Head Together (NHT) Untuk Meningkatkan Keterampilan Metakognitif Siswa Pada Materi Asam Basa Di Kelas XI. UNES Journal of Chemical Education, 6(3), 440-445.

https://doi.org/10.1017/CBO9781107415324.004

Saleh, S.E. (2019). Critical thinking as a 21 st century skill: conceptions, implementation and challenges in the EFL classroom. European Journal of Foreign Language Teaching, 4(1), 1-16.

https://doi.org/10.5281/zenodo.2542838

Saputro, D.R., \& Gunansyah, G. (2011). Peningkatan Keterampilan Berpikir Kritis Melalui Model Pembelajaran Inkuiri Pada Pembelajaran IPS Di Sekolah Dasar. Jurnal Unesa.

SCIT 1020 (2013). Rubrics for Critical Thinking / Analytical Questions.

Skerrit, O., Fletcher, M., \& Kearney, J. (2015). Critical Reflection. Professional Learning in Higher Education and Communities. Palgrave. https://doi.org/10.1057/9781137455185

Stolz, M., Witteck, T., Marks, R., \& Eilks, I. (2014). Reflecting Socio-Scientific Issues for Science Education Coming from the Case of Curriculum Development on Doping in Chemistry Education. Eurasia Journal of Mathematics, Science and Technology Education, 9(4), 361-370. https://doi.org/10.12973/eurasia.2014.945a

Suryawati, E., \& Osman, K. (2017). Contextual Learning: Innovative Approach towards the Development of Students' Scientific Attitude and Natural Science Performance. EURASLA Journal of Mathematics, Science and Technology Education, 14(1). https://doi.org/10.12973/ejmste/79329

Tarhan, L., \& Acar-Sesen, B. (2012). Jigsaw cooperative learning: Acid-base theories. Chemistry Education Research and Practice, 13(3), 307-313. https://doi.org/10.1039/c2rp90004a

Yunarti, T. (2011). Pengarub Metode Socrates Terbadap Kemampuan dan Disposisi Berpikir Kritis Matematis Siswa Sekolah Menengah Atas. Universitas Pendidikan Indonesia (UPI).

Published by OmniaScience (www.omniascience.com)

Journal of Technology and Science Education, 2022 (www.jotse.org)

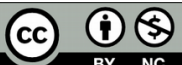

Article's contents are provided on an Attribution-Non Commercial 4.0 Creative commons International License. Readers are allowed to copy, distribute and communicate article's contents, provided the author's and JOTSE journal's names are included. It must not be used for commercial purposes. To see the complete licence contents, please visit https://creativecommons.org/licenses/by-nc/4.0/. 